\title{
Inovasi Pembelajaran Anak Usia Dini Berbasis Kearifan Lokal melalui kegiatan Eco print di masa pandemic covid-19
}

\author{
Siti Misra Susanti ${ }^{\bowtie}$, Henny $^{2}$, Marwah $^{3}$ \\ Pendidikan Guru Pendidikan Anak usia Dini, Universitas Muhammadiyah Buton \\ DOI: $\underline{10.31004 / \text { obsesi.v5i2.594 }}$
}

\begin{abstract}
Abstrak
Penelitian ini bertujuan untuk mengetahui implementasi kegiatan mencetak dengan tehnik eco-Print pada anak usia dini khususnya usia 4-6 tahun yang berbasis kearifan lokal daerah pinggiran Kota Baubau. Metode penelitian ini adalah kualitatif deskriptif yang berlokasi di Kota Baubau dan Kabupaten Buton. Observasi dilakukan dengan mengamati secara langsung kegiatan anak usia dini dalam proses mencetak dengan tehnik eco-print serta mengamati bagaimana kegiatan eco-print dapat menstimulasi berbagai aspek perkembangan anak usia dini. Pengumpulan data dilakukan dengan observasi, wawancara dan dokumentasi. Hasil penelitian menunjukkan bahwa pembelajaran mencetak dengan tehnik eco-print merupakan suatu inovasi pembelajaran pada anak usia dini berbasis kearifan lokal untuk menstimulasi berbagai aspek perkembangan anak usia dini. Selain itu, bahan alam yang ada di sekitar anak menjadi inspirasi dan sumber belajar anak usia dini dalam mencipta suatu karya seni.
\end{abstract}

Kata Kunci: inovasi pembelajaran; eco-print; kearifan lokal.

\begin{abstract}
This study aims to determine the implementation of printing activities with eco-print techniques in early childhood, especially those aged 4-6 years based on local wisdom in the suburbs of Baubau City. This research method is descriptive qualitative located in the City of Baubau and Buton Regency. Observations were made by directly observing early childhood activities in the printing process with eco-print techniques and observing how eco-print activities can stimulate various aspects of early childhood development. Data collection was carried out by observation, interviews and documentation. The results showed that learning to print with the eco-print technique is an innovation in early childhood learning based on local wisdom to stimulate various aspects of early childhood development. In addition, natural materials that are around children become inspiration and learning resources for early childhood in creating works of art.
\end{abstract}

Keywords: learning innovation; eco-print; local culture.

Copyright (c) 2021 Siti Misra Susanti, Henny, Marwah

$\square$ Corresponding author:

Email Address : sitimisra764@gmail.com (Buton, Bau-bau, Sulawesi Tenggara, Indonesia)

Received 12 October 2020, Accepted 5 February 2021, Published 10 February 2021 


\section{PENDAHULUAN}

Pendidikan untuk anak penting dibina dan ditumbuhkembangkan sejak dini agar tercipta generasi yang cerdas pada tahun-tahun mendatang. Pendidikan juga merupakan suatu perubahan yang dinamis bagi setiap individu untuk mempengaruhi perkembangan fisik, jiwa rasa dan kehendak setiap manusia. Nuraeni et al., (2019) mengungkapkan bahawa berbagai upaya dilakukan oleh pemerintah untuk mencerdaskan anak bangsa melalui kegiatan-kegiatan keterharuan yang ditujukan kepada pendidik atau pengelola lembaga Pendidikan Anak Usia Dini (PAUD) di Indonesia. Sebagaimana Suryana, (2013) mengatakan bahwa pendidikan menumbuh kembangkan potensi-potensi yang dalam dalam dirinya untuk menjadi generasi yang cerdas.

Berbagai upaya dilakukan oleh pengelola lembaga PAUD dalam meningkatkan kualitas pendidikan baik dalam inovasi pembelajaran maupun metode evaluasi yang digunakan untuk meningkatkan kualitas program yang dijalankan. Utami et al., (2019) mengungkapkan bahwa para pengelola lembaga PAUD dan guru-guru anak usia dini serta stakeholder berlomba-lomba menciptakan berbagai inovasi pembelajaran untuk anak yang update terhadap perkembangan kemajuan ilmu pengetahuan dan teknologi sebagaimana yang dijelaskan oleh (Utami et al., 2019) bahwa lembaga PAUD harus memiliki kualitas yang baik untuk memberikan manfaat dalam jangka pendek dan jangka panjang bagi kehidupan anak usia dini. Sistem pendidikan saat ini mengadopsi berbagai cara dalam mengadakan perubahan. Perubahan terjadi seiring dengan lajunya perkembangan ilmu pengetahuan dan teknologi (Tilaar, 1998).

Inovasi pembelajaran dirancang sesuai dengan kondisi, budaya dan kebutuhan anak usia dini pada masing-masing lembaga maupun daerah dimana anak belajar. (Munawar et al., 2013) menjelaskan bahwa inovasi pembelajaran berbasis kondisi budaya berdasar kearifan lokal dapat meningkatkan pembelajaran anak usia dini. Menurut (Mawati et al., 2020) menjelaskan bahwa inovasi pembelajaran merupakan pembaharuan/ perubahan kearah yang lebih baik disesuaikan dengan kebutuhan anak dalam melaksanakan proses pembelajaran. Dewi \& Suryana, (2020) berpendapat bahwa pada dasarnya pembelajaran di PAUD bertujuan untuk mengenalkan anak pada dunia nyata tentang mengenal lingkungan dan alam sekitarnya demi mangasah minat dan kemampuan setiap anak. Dalam Undang-Undang Sistem Pendidikan Nasional Nomor. 20 tahun 2003 (Indonesia, 2003) menyatakan bahwasanya setiap anak berhak memperoleh pendidikan dan pengajaran dalam rangka pengembangan pribadinya dan tingkat kecerdasannya sesuai dengan minat dan bakat.

Untuk menunjang ketercapaian minat dan bakat tersebut, guru berupaya semaksimal mungkin melahirkan berbagai inovasi pembelajaran sesuai dengan kebutuhan dan karakteristik anak sehingga proses pelaksanaan pembelajaran lebih menarik dan menyenangkan.

Berdasarkan pada pengamatan proses pembelajaran di berbagai lembaga PAUD di kota Baubau, proses pembelajaran anak usia dini terbatas pada buku-buku sebagai alat dan media belajar di sekolah maupun rumah. Kegiatan belajar anak dibatasi pada kegiatan mewarnai gambar-gambar dengan krayon ataupun pensil warna, menebalkan huruf atau angka, menghubungkan bilangan dan lambangnya, menulis kata dan menggambar benda yang diarahkan oleh guru sesuai dengan tema-tema yang telah ditentukan. Kegiatan ini sangat monoton pada beberapa perkembangan anak. Media ataupun kegiatan seperti ini, kurang memberikan pembelajaran yang bermakna untuk anak dalam proses tumbuh kembangnya. Media yang digunakan masih konvensional sehingga berdampak pada kurangnya minat anak dalam belajar ujar Panjaitan et al., (2020).

Media pembelajaran merupakan alat perantara guru dan peserta didik dalam proses pembelajaran. (Gerlach \& Ely Donal, 2014) mengungkapkan bahwa media tidak hanya dibatasi pada buku atau materi sebagai alat, tetapi manusia dan kegiatan-kegiatan pendukung lainnya untuk mengembangkan pengetahuan dan keterampilan serta sikap juga merupakan 
media pembelajaran. Khotimah et al., (2020) menjelaskan bahwa salah satu cara yang paling efektif dalam pengelolaan kelas adalah memberikan media yang menarik pada anak.

Merujuk dari teori diatas, segala sesuatu yang ada di sekitar anak dapat dijadikan sebagai sumber belajar untuk mengembangkan maupun menstimulasi berbagai aspek perkembangan anak. Olehnya itu, guru harus berinovasi memanfaatkan alam sekitar di sekitar untuk menunjang pembelajaran anak usia dini. Menurut Nurdin \& Anhusadar, (2020) menyatakan bahwa proses pembelajaran tidak hanya terbatas pada ruang kelas tetapi juga guru menggunakan bahan di sekitar anak untuk media pembelajaran anak untuk mengembangkan minat dan bakat sesuai dengan tahapan perkembangan

Winarni dalam Ana Mulia (2017) menjelaskan bahwa lingkungan sekitar anak dapat dijadikan sebagai sumber belajar yang tidak terbatas jumlahnya. Olehnya itu, guru dapat mendesain dan merancang media maupun bahan ajar secara kreatif dan bervariasi agar pembelajaran lebih efektif, menarik dan menyenangkan untuk anak dalam proses belajarnya di rumah maupun di sekolah (Mulia, n.d.).

Guru PAUD dituntut untuk mampu mengimplementasikan pembelajaran yang menyenangkan agar seluruh potensi anak berkembang sesuai dengan tahapan perkembangannya. Zulfitrah \& Eliza, (2020) menambahkan bahwa pembelajaran yang diberikan kepada anak seyogyanya disesuaikan dengan kebutuhan serta stimulasi yang tepat dalam mengoptimalkan capaian perkembangannya.

Sukma Vavilya (2014) berpendapat bahwa pemanfaatan alam sekitar bagi anak usia dini dapat membantu proses pembelajaran dikarenakan sumber belajar dengan dengan anak, kemudian anak dapat bermian-main dengan bahan yang sebelumnya telah dikenal dan diketahui sehingga perubahan tingkah laku yang diharapkan oleh guru tercapai secara optimal (Ambarwati, 2014).

Adapun pemanfaatan bahan yang ada di sekitar sebagai media pembelajaran untuk anak disesuaikan dengan potensi ataupun kearifan lokal daerah masing-masing. Nadlir (2016) menjelaskan bahwa kearifan lokal merupakan buah kreativitas suatu masyarakat atau komunitas dalam memenuhi kebutuhannya atau memecahkan masalah dengan memanfaatkan potensi maupun sumber daya alam yang terdapat di lingkungan sehari-hari. Olehnya itu, penerapan media pembelajaran yang berbasis kearifan lokal dapat membantu guru untuk merancang media maupun model pembelajaran yang inovatif sehingga proses pembelajaran lebih variatif dan menyenangkan untuk anak usia dini.

Salah satu model pembelajaran yang yang berbasis kearifan lokal didesain oleh guru PAUD untuk menciptakan pembelajaran yang menyenangkan adalah melalui kegiatan ecoprint. Flint dalam (DS \& Alvin, 2019) menjelaskan bahwa eco-print adalah kegiatan mentrasfer warna dan bentuk dengan menempelkan tanaman yang memiliki pigmen warna pada kain yang berserat dengan kontak langsung. Pemilihan tanaman yang memiliki sensitivitas terhadap panas merupakan faktor penting dalam mengestraksi pigmen warna. Kegiatan pembelajaran dengan menempel dan bermain warna merupakan kegiatan menyenangkan untuk anak usia dini. Adapun elemen tumbuhan yang dapat digunakan untuk kegiatan tehnik eco-print adalah bunga, daun, batang, kulit, buah dan akar.

Baubau merupakan daerah tropis, dimana banyak ditemukan tanaman-tanaman yang memiliki pigmen warna dan tanaman yang memiliki sensitivitas terhadap panas. Namun tanaman-tanaman yang ada tidak pernah digunakan baik untuk pewarnaan alami ataupun sebagai bahan pembelajaran.

Untuk memperjelas kajian penggunaan tehnik eco-print dalam pembelajaran untuk anak usia dini, Irianingsih (2018:7) menjelaskan bahwa kegiatan eco-print adalah suatu proses memindahkan bentuk (pola) dedaunan ataupun bunga-bunga keatas permukaan kain secara langsung (Masyitoh \& Ernawati, n.d.). Kegiatan ini dilakukan dengan mencetak daun-daun diatas permukaan kain putih polos dengan dipukul-pukul untuk menghasilkan warna sesuai motif (pola) unik dan menarik dengan menunjukkan warna warna alami tanpa menggunakan 
bahan kimia. Kegiatan seperti mencap daun maupun alat lainnya pernah dilakukan oleh guru namun guru perlu berinovasi untuk mendesain yang lebih menarik untuk pembelajaran anak.

Kegiatan eco-print untuk anak usia dini dipusatkan pada proses pembuatan produk dengan tujuan untuk menstimulasi berbagai aspek aspek perkembangan anak. Sebagaimana penelitian yang dilakukan oleh (Kharishma \& Septiana, 2019). Proses kegiatan eco-print untuk pembelajaran anak usia dini berkaitan dengan teori surplus yang dikemukakan oleh Herber Spenser menjelaskan bahwasannya anak usia dini memiliki energi yang berlebih sehingga perlu ada media untuk disalurkan agar energi di dalam tubuhnya memiliki keseimbangan (Astuti \& Fatimaningrum, 2016). Energi yang dikeluarkan pada proses eco-print berupa kegiatan memukul daun hingga menghasilkan warna pada dapat menyeimbangkan energi berlebih dalam tubuh anak sehingga perkembangan fisik motorik dan perkembangan emosional anak usia dini dapat terstimulasi dengan baik. Roostin, (2020) menjelaskan bahwa perkembangan motorik anak merupakan keterampilan yang perlu dikembangkan, demi menghasilkan kkreativitas dalam memanifestasi aktualisasi diri anak.

Perkembangan anak pada usia 4-6 tahun, tahapan berpikir anak didominasi pada halhal atau benda-benda yang sifatnya nyata (kongkrit) (Alhaddad, 2012). Berdasarkan pernyataan bahwa tahapan perkembangan anak memiliki ciri khas masing-masing yang dimiliki setiap anak mulai dari berpikir kongkrit dan bereksplorasi dengan lingkungan tempat belajar anak. Untuk itu, guru seyogyanya menggunakan media-media atau benda-benda yang konkret, unik dan menarik serta dapat ditemukan di sekitar anak sebagai media untuk berinovasi dan berkreasi. Menurut Pramitasari et al., (2018) mengungkapkan bahwa inovasi pembelajaran dapat melahirkan berbagai perubahan-perubahan perilaku berupa kemampuan dalam hal pengetahuan, sikap, dan keterampilannya.

Keterampilan sikap dan pengetahuan anak akan melahirkan berbagai inovasi pembelajaran salah satunya Kegiatan belajar/bermain dengan tehnik eco-print menjadi salah satu inovasi pembelajaran untuk anak usia dini yang sifatnya kongkrit, unik, menarik dan bahannya tersedia di sekitar anak.

Pembelajaran tehnik eco-print untuk anak usia dini didesain dengan bermain dengan tanaman sekitar dan menggunakan kain bekas yang memungkinkan anak dapat berinteraksi dalam pembelajaran yang menarik dan menyenangkan sesuai dengan kebutuhannya sehingga terjadi perubahan atau perkembangan pada diri anak. Dengan demikian peneliti mengadakan penelitian dengan judul inovasi pembelajaran anak usia dini berbasis kearifan lokal melalui kegiatan eco-print.

Adapun beberapa tujuan penelitian ini adalah (1) memberikan variasi pembelajaran pada anak usia dini, (2) memberikan solusi atas keterbatasan media yang digunakan, (3) menjadikan anak untuk lebih kreatif (4) memberikan pengetahuan dan wawasan luas kepada masayarakat luas tentang pembelajaran yang berbasis kearifan lokal melalui kegiatan eco-print untuk anak usia dini.

\section{METODOLOGI}

Penelitian ini menggunakan metode penelitian kualitatif deskriptif. Penelitian ini dilakukan dengan observasi awal mengenai pembelajaran yang berbasis eco-print. Metode penelitian ini bertujuan menggambarkan kejadian ilmiah dimana peneliti terlibat langsung dalam kegiatan pembelajaran. Penelitian ini berlokasi di kota Baubau, penelitian ini dilakukan selama 6 minggu yang menjadi subjek penelitian adalah anak-anak usia 4-6 tahun. (Moleong, 2006).

Terkait penelitian ini, maka peneliti terlibat langsung dan memberikan interpretasi terhadap suatu fakta atau gejala tentang pembelajaran yang berbasis kearifan lokal dengan melalui kegiatan eco-print. Kegiatan pembelajaran ini melibat anak usia dini yaitu anak usia 4-6 tahun. Tahap awal dalam penelitian ini yaitu tahap persiapan, pada tahap ini peneliti mempersiapkan alat-alat berupa instrumen penelitian yang berkaitan dengan dengan observasi awal tahap kedua, tahap pelaksanaan penelitian, tahap ini peneliti mencari 
informasi dengan melakukan wawancara kepada masyarakat, orang tua, bahkan anak usia dini untuk memperoleh data yang valid. Teknik obsevasi dilakukan untuk mengamati aktivitas anak dalam kegiatan pembelajaran. Teknik dokumentasi dilakukan untuk memperkuat temuan dalam penelitian.

Tahap ketiga adalah pengolahan data, terdiri atas tiga tahap yaitu: (1) reduksi data, merupakan proses pemilihan, pemusatan perhatian, penyederhanaan dan transformasi data mentah yang diambil di lapangan. Kemudian data-data ini direduksi dalam hal ini data-data yang direduksi adalah data-data yang tidak mendukung fokus penelitian. (2) Display data yaitu penyajian data atau informasi yang telah direduksi yang kemudian disajikan dalam bentuk gambar, untuk menggambarkan keseluruhan data atau informasi dapat memudahkan penarikan kesimpulan (3) verifikasi (penarikan kesimpulan) bertujuan untuk menganalisis keseluruhan data-data yang berkaitan dengan fokus penelitian.
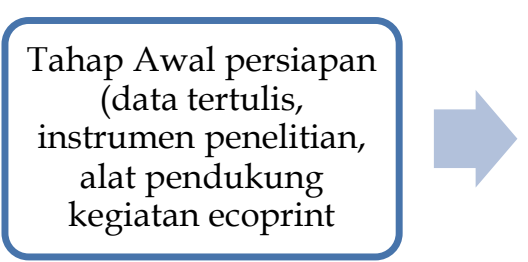

\section{Pengolahan data}

Reduksi data, display, verifikasi (penarikan kesimpulan)

\section{Gambar 1. Desain penelitian}

\section{HASIL DAN PEMBAHASAN}

\section{Inovasi Pembelajaran Anak Usia Dini}

Pembelajaran inovatif bagi anak usia dini merupakan pembelajaran berpusat pada aktivitas anak yang dilakukan dengan mengkolaborasikan pengetahuan bersama teman sebaya. Kegiatan pembelajaran yang menarik, menyenangkan dapat memfasilitasi berbagai aspek perkembangan anak usia dini. Untuk mendukung tercapainya aspek perkembangan anak dalam pembelajaran dibutuhkan pembaharuan model dan inovasi yang unik serta mudah ditemukan disekitar anak. Salah satu kegiatan yang didesain untuk inovasi pembelajaran ini adalah kegiatan eco- print.

Munawar et al., (2013) memberikan definisi pembelajaran inovatif merupakan bentuk pembelajaran yang menarik, menyenangkan, dan dapat memfasilitasi perkembangan dan kebutuhan anak. Pembelajaran inovatif menggabungkan atau mengolaborasikan beberapa aspek penting yang dapat memperkaya isi pembelajaran menjadi suatu yang baru.

\section{Pembelajaran Eco-print berbasis Kearifan Lokal}

Proses pembelajaran dengan eco-print didesain dan dirancang untuk memperkaya isi pembelajaran agar menjadi sesuatu yang baru berdasar pada kebutuhan dan karakteristik anak usia dini dengan berbasis kearifan lokal. Menurut Ernawati \& Sari, (2020) menjelaskan bahwa kearifan lokal memberikan inspirasi dalam menciptakan suatu karya yang memiliki potensi cukup krusial untuk menumbuh kembangkan budaya sesuai dengan perkembangan zaman dengan tidak mengurangi nilai-nilai karakter khas dari budaya tersebut. Adapun desain pembelajaran eco-print digambarkan pada gambar 2.

\section{Menyiapkan Alat dan bahan yang digunakan}

Proses kegiatan eco-print untuk anak usia dini diawali dengan menyiapkan alat dan bahan untuk membuat produk yang diinginkan. Guru menyiapkan alat dan bahan yang diperlukan anak untuk proses kegiatan antara lain: kain polos, isolasi/kertas mika, batu/palu, gunting/pisau dan kapur sebagai bahan penetrasi warna agar bahan yang dipakai tidak mudah luntur dan zat daun tidak berbahaya. Ukuran alat dan bahan disesuaikan dengan kematangan motorik dan kemampuan otot anak sehingga anak mudah menggunakannya. Kemudian guru menjelaskan fungsi dari masing-masing alat dan bahan yang disediakan. 
Berdasarkan hasil penelitian yang ditemukan oleh (Fatmala \& Hartati, 2020) menjelaskan bahwa pembelajaran eco-print sebelumnya sudah diadakan penelitian mengenai pengaruh membatik eco-print dengan kreativitas seni anak di Taman Kanak-kanak. Menurut Irianingsih (2018:4) teknik eco-print ialah salah satu cara mengolah kain putih dengan memanfaatkan berbagai tumbuhan yang bisa mengeluarkan warna-warna alami.

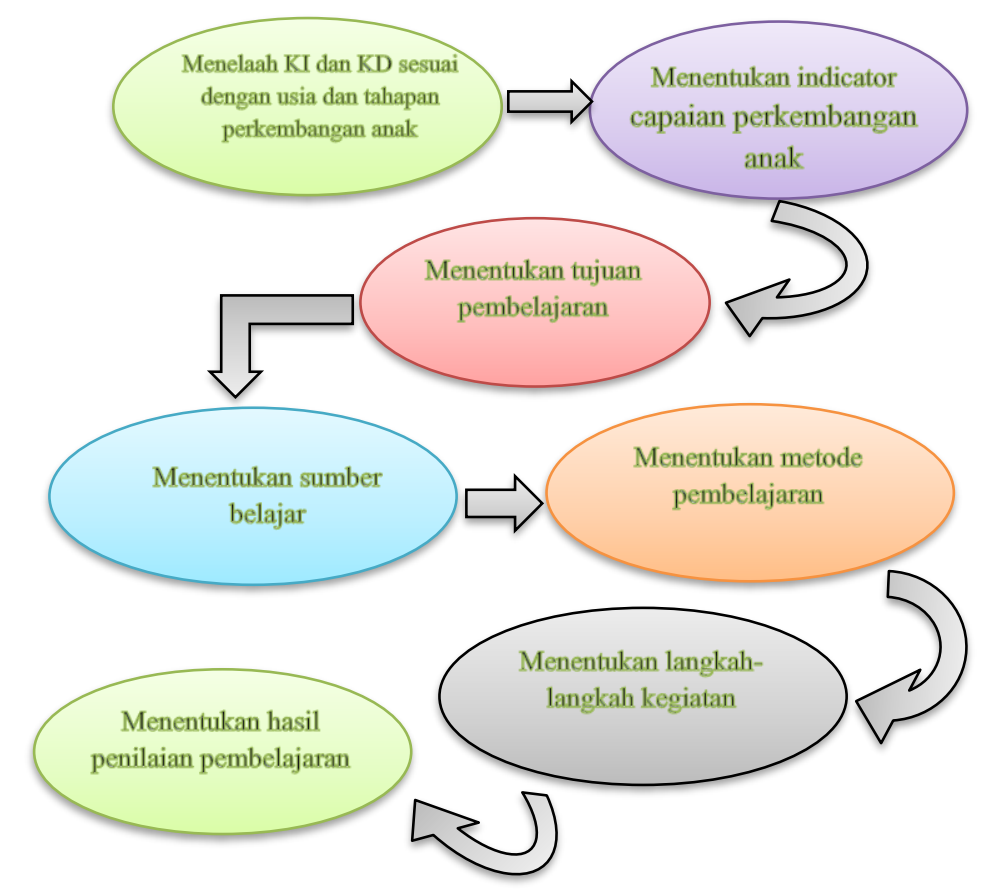

\section{Gambar 2. Desain Inovasi Pembelajaran dengan tehnik eco-print}

Adapun langkah-langkah kegiatan penelitian inovasi pembelajaran berbasis kearifan lokal melalui kegiatan eco-print pada gambar 3.

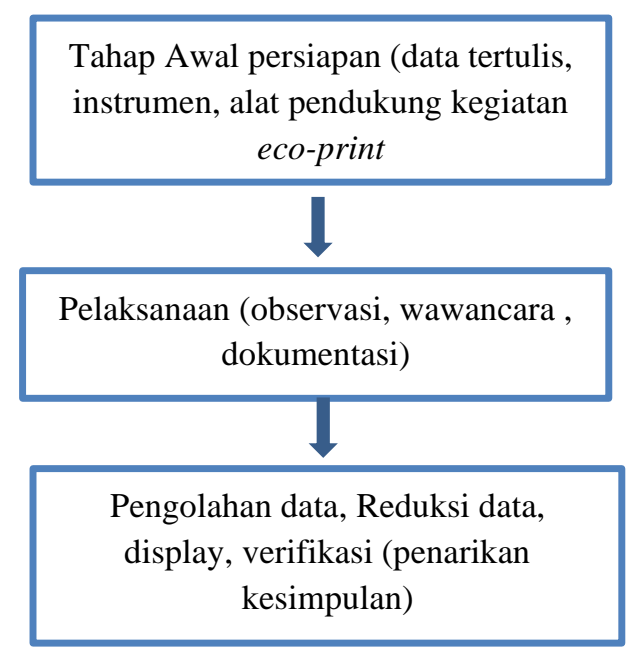

Gambar 3. langkah-langkah kegiatan penelitian inovasi pembelajaran berbasis kearifan lokal melalui kegiatan eco-print

Sebelum memulai kegiatan, guru mengarahkan anak untuk mengidentifikasi kembali alat dan bahan yang ada dan menyebutkan kembali fungsi alat dan bahan yang telah disediakan dengan tujuan untuk mengembangkan aspek kognitif maupun bahasa anak. Masing-masing anak mengklasifikasi alat dan bahan yang tersedia didepannya dan 
menyebutkan fungsi dari alat dan bahan tersebut. Kegiatan ini dilaksanakan dengan bermain dan bernyanyi agar kegiatan menyenangkan dan menarik perhatian anak.

\section{Memilih daun secara bebas yang ada disekitar anak}

Setelah kegiatan pengenalan alat dan bahan oleh anak-anak, guru memberikan kebebasan kepada anak untuk memilih dedaunan yang disukai di lingkungan sekitarnya sebagai bahan dasar pembuatan eco-print. Kegiatan ini menstimulasi anak usia dini untuk bereksplorasi dan mengasah kemampuan berpikir serta menemukan ide ide baru tentang kegiatan yang dilakukan sebagaimana yang dijelaskan oleh (Asmara, 2020) Anak-anak sangat antusias melakukan kegiatan ini secara bebas
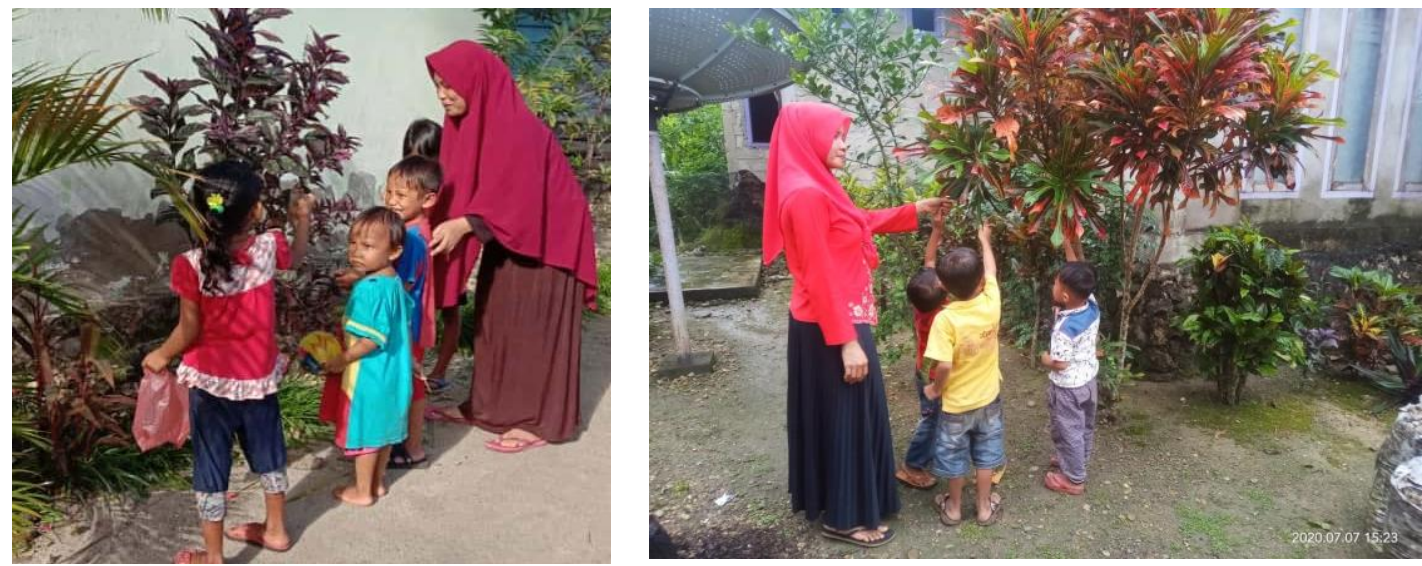

Gambar 4. Kegiatan memilih daun

Pada kegiatan di gambar 4, anak-anak diarahkan oleh guru untuk tidak saling berebut dengan tujuan untuk menstimulasi perkembangan sosial emosional anak. Selain itu, anakanak dapat mengklasifikasi daun sesuai dengan bentuk dan warna yang diinginkan. Kegiatan memetik daun dilakukan dengan tangan tanpa benda tajam dengan tujuan untuk mengembangkan motorik halus anak usia dini

\section{Prosedur kegiatan dan tata cara pembuatan produk eco-print}

Setelah kegiatan menyiapkan alat dan bahan untuk proses belajar melalui eco-print kemudian memilih daun yang ada di sekitar anak sebagai bahan dasar proses pembelajaran selanjutnya guru menjelaskan langkah-langkah kegiatan bermain dengan eco-print sesuai dengan karakteristik anak usia dini.

Guru memulai kegiatan belajar dengan berdoa terlebih dahulu yang dipimpin oleh salah satu anak untuk mengembangkan nilai agama dan moral serta sosial emosional terkait dengan kepemimpinan. Selanjutnya guru mulai menjelaskan tema kegiatan sambil bercakapcakap dengan anak tentang tema "Tanaman". Beberapa anak diamati dapat bercerita dan bercakap-cakap tentang pengetahuannya akan tanaman yang ada sekitar dengan penuh keceriaan. Sebelum masuk pada kegiatan inti, guru bersama anak menyanyikan beberapa lagu sesuai tema. Kegiatan ini dapat menstimulasi perkembangan bahasa dan seni anak usia dini.

Kegiatan inti dimulai dengan memberikan kebebasan kepada masing-masing anak untuk memilih daun dan mempola corak/bentuk sesuai dengan keinginannya di atas kain polos yang telah disediakan. Anak-anak terlihat antusias melaksanakan kegiatan mempola/membentuk corak dengan daun. Namun beberapa diantaranya masih bingung melakukan kegiatan mempola corak tersebut senada dengan Prayitno, (2019) menuliskan bahwa guru harus mendampingi dan membimbing anak agar dapat berkreasi sesuai keinginanya. Pada kegiatan ini, anak terstimulasi untuk mengasah kemampuan berpikir dan berkreasi (kognitif) sehingga dapat mencipta suatu karya seni sesuai dengan usia dan tahapan perkembangannya. Sebagai gambaran kegiatan pembelajaran, dapat dilihat pada gambar 5 . 

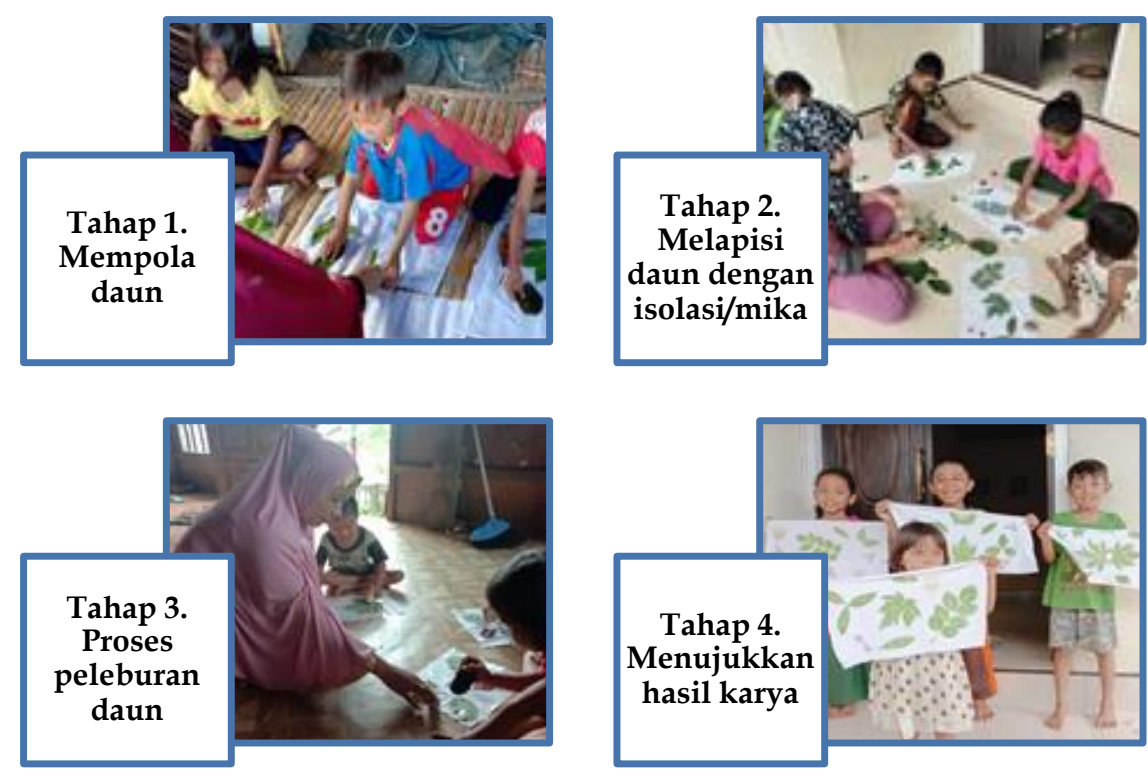

Gambar 5. Kegiatan pembelajaran eco-print

Selanjutnya masing-masing anak dibantu oleh guru untuk menempelkan mika/isolasi/kertas plastik diatas kain dan daun yang sudah dibentuk agar corak daun tidak bergerak pada proses peleburan dan pemindahan warna daun pada kain. Kemudian dilakukan kegiatan peleburan daun yang sudah dipola coraknya agar daun yang memiliki pigmen warna dapat tercorak pada kain. Daun dileburkan dengan cara ditumbuk dengan palu/batu dengan ukuran yang mampu digunakan oleh anak. Masing-masing anak terlihat senang dan bersemangat melakukan kegiatan tersebut.

Proses peleburan daun dan pemindahan warna pada kain sebagai corak dapat menstimulasi perkembangan fisik motorik kasar motorik halus dengan mengkombinasikan mata dan tangan untuk menghasilkan karya yang indah. Selain itu kegiatan menumbuk/meleburkan daun merupakan proses pelepasan energi berlebihan yang ada dalam diri masing-masing anak sehingga berdampak pada keseimbangan emosi yang ada dalam diri anak. Menurut (Rahutami et al., 2020) menjelaskan bahwa Proses pemanfaatan tumbuhan dengan memanfaatkan bahan di sekitarnya sebagai pewarna alami.

Setelah kegiatan pemindahan pigmen warna daun ke serat kain maka selanjutnya anak-anak menunjukkan hasil karyanya untuk menstimulasi sosial emosional anak terkait dengan kemandirian dan bangga terhadap hasil karya yang dibuatnya. Anak-anak berlombalomba menunjukkan hasil karyanya kepada guru. Untuk kegiatan finalisasi, anak-anak di arahkan untuk menjemur masing-masing hasil karya yang telah dilakukan agar warna dan corak dapat bertahan lama pada serat kain.

Melalui kajian tersebut peneliti berharap para pendidik anak usia dini selalu berinovasi mendesain pembelajaran untuk anak yang berbasis pada pencapaian perkembangan anak. Peneliti juga berharap hasil penelitian dapat digunakan oleh pendidik anak usia dini dalam mengembangkan berbagai aspek perkembangan anak yang lebih variatif dengan media yang tersedia di sekitar anak. Kegiatan eco-print dapat diterapkan dalam pembelajaran di dalam maupun di luar kelas. Berdasarkan penelitian yang dilakukan oleh Yeyen Fatmala "pengaruh membatik eco-print terhadap perkembangan kreativitas anak di taman kanak-kanak" Melalui kegiatan membatik eco-print ini anak diharapkan mampu menciptakan sebuah karya yang menarik dengan berbagai motif dari bunga dan dedaunan yang tentunya anak bebas memilih bunga dan dedaunan mana yang diinginkan anak. Selain itu, membatik eco-print ini belum pernah digunakan sehingga merupakan kegiatan inovasi di Taman Kanak-kanak dengan menggunakan bahan yang digunakan menarik bagi anak dan mudah didapatkan. 


\section{KESIMPULAN}

Implementasi kegiatan mencetak dengan tehnik eco-print pada anak usia 4-6 tahun daerah pinggiran Kota Baubau merupakan suatu bentuk inovasi pembelajaran mencetak berbasis kearifan lokal yang dapat menstimulasi berbagai aspek perkembangan anak. Melalui kegiatan mencetak dengan eco-print anak dapat terinspirasi menciptakan karya dan mencintai lingkungan sekitar sebagai sumber belajar alami.

\section{UCAPAN TERIMA KASIH}

Segala puji bagi Allah, Tuhan yang Maha Esa atas rahmat dan karunia yang telah diberikan sehingga penulis dapat menyelesaikan seluruh rangkaian penelitian. Terima kasih pula kepada semua pihak yang telah membantu proses penyelesaian penelitian ini. Tulisan ini masih terdapat banyak kekurangan sehingga diperlukan perbaikan. Olehnya itu, penulis dengan kerendahan hati menerima kritik dan saran dari semua pihak untuk pengembangan dan perbaikan kearah yang lebih baik. Semoga penelitian ini dapat bermanfaat untuk masyarakat luas khususnya para guru-guru PAUD, pengelola lembaga maupun peneliti atau praktisi PAUD.

\section{DAFTAR PUSTAKA}

Alhaddad, I. (2012). Penerapan teori perkembangan mental piaget pada konsep kekekalan panjang. Infinity Journal, 1(1), 31-44.

Ambarwati, S. V. (2014). Pemanfaatan Bahan Alam untuk Meningkatkan Kreativitas Membuat Mozaik pada Siswa di Sekolah Dasar. Jurnal Penelitian Pendidikan Guru Sekolah Dasar, 2(2), 1-10.

Asmara, D. A. (2020). Penerapan Teknik Ecoprint pada Dedaunan Menjadi Produk Bernilai Jual. Abdi Seni: Jurnal Pengabdian Kepada Masyarakat, 1(2), 16-26.

Astuti, B., \& Fatimaningrum, A. S. (2016). Pengembangan Panduan Permainan Untuk Engoptimalkan Perkembangan Sosial Emosional Anak Usia Dini. Jurnal Pendidikan Anak, 5(1).

Dewi, I., \& Suryana, D. (2020). Analisis Evaluasi Kinerja Pendidik Pendidikan Anak Usia Dini di PAUD Al Azhar Bukittinggi. Jurnal Obsesi: Jurnal Pendidikan Anak Usia Dini, 4(2), 1051-1059.

DS, B. W., \& Alvin, M. A. (2019). Teknik Pewarnaan Alam Eco Print Daun Ubi Dengan Penggunaan Fiksator Kapur, Tawas Dan Tunjung. Jurnal Litbang Kota Pekalongan, 17.

Ernawati, E., \& Sari, R. N. (2020). Representasi Kesadaran Budaya Lokal Perupa Dalam Penciptaan Karya Seni Rupa Dan Desain Di Era Kontemporer (Studi Kasus: Perupa di Yogyakata).

Fatmala, Y., \& Hartati, S. (2020). Pengaruh Membatik Ecoprint terhadap Perkembangan Kreativitas Seni Anak di Taman Kanak-Kanak Islam Budi Mulia. Jurnal Pendidikan Tambusai, 4(2), 1143-1155.

Gerlach, S. V., \& Ely Donal, P. (2014). Teaching And Madian-A Systematic Approach Arsyad.

Indonesia, P. R. (2003). Undang-undang Republik Indonesia nomor 20 tahun 2003 tentang sistem pendidikan nasional. Jakarta: Pemerintah Republik Indonesia.

Kharishma, V., \& Septiana, U. (2019). Vidya Kharishma Pelatihan Teknik Ecoprint Untuk Guru Paud. Prosiding: Seni, Teknologi, Dan Masyarakat, 2, 183-187.

Khotimah, S. H., Sunaryati, T., \& Suhartini, S. (2020). Penerapan Media Gambar Sebagai Upaya dalam Peningkatan Konsentrasi Belajar Anak Usia Dini. Jurnal Obsesi: Jurnal Pendidikan Anak Usia Dini, 5(1), 676-685.

Masyitoh, F., \& Ernawati, E. (2020). Pengaruh mordan tawas dan cuka terhadap hasil pewarnaan eco print bahan katun menggunakan daun jati (Tectona Grandis). Gorga: Jurnal Seni Rupa, 8(2), 387-391. 
Mawati, A. T., Permadi, Y. A., Rasinus, R., Simarmata, J., Chamidah, D., Saputro, A. N. C., Purba, B., Ritonga, M. W., Sudono, E. P., \& Purba, B. (2020). Inovasi Pendidikan: Konsep, Proses dan Strategi. Yayasan Kita Menulis.

Moleong, L. J. (2006). Metode penelitian kualitatif edisi revisi. Bandung: Remaja Rosdakarya.

Mulia, A. (2020). Sumber Belajar Yang Didapat Dari Lingkungan Sekitar Melalui Pembelajaran Tematik. 1(1).

Munawar, M., Prasetyo, A., \& Pusari, R. W. (2013). Pengembangan model pembelajaran inovatif melalui pendekatan in house training berbasis kearifan budaya lokal. PAUDIA: Jurnal Penelitian Dalam Bidang Pendidikan Anak Usia Dini, 2(1 mei).

Nuraeni, L., Andrisyah, A., \& Nurunnisa, R. (2019). Efektivitas Program Sekolah Ramah Anak dalam Meningkatkan Karakter Anak Usia Dini. Jurnal Obsesi: Jurnal Pendidikan Anak Usia Dini, 4(1), 20-29.

Nurdin, N., \& Anhusadar, L. (2020). Efektivitas Pembelajaran Online Pendidik PAUD di Tengah Pandemi Covid 19. Jurnal Obsesi: Jurnal Pendidikan Anak Usia Dini, 5(1), 686697.

Panjaitan, N. Q., Yetti, E., \& Nurani, Y. (2020). Pengaruh Media Pembelajaran Digital Animasi dan Kepercayaan Diri terhadap Hasil Belajar Pendidikan Agama Islam Anak. Jurnal Obsesi: Jurnal Pendidikan Anak Usia Dini, 4(2), 588-596.

Pramitasari, M., Yetti, E., \& Hapidin, H. (2018). Pengembangan media sliding book untuk pengenalan sains kehidupan (life science) kelautan untuk anak usia 6-7 tahun. Jurnal Pendidikan Usia Dini, 12(2), 281-290.

Prayitno, P. (2019). Pembelajaran batik tetes lilin sebagai alternatif teknik membatik sederhana pada mahasiswa PAUD. Jurnal Pendidikan Anak, 8(1), 38-47.

Rahutami, A. I., Hastuti, R., Kekalih, W., \& purnamasari, V. (2020). Ecoprint: Pemanfaatan Tumbuhan Di Alam Bandungan Untuk Menciptakan Nilai Tambah Pada Kain.

Roostin, E. (2020). Upaya Meningkatkan Motorik Halus dan Kreativitas Anak Melalui Teknik Membatik Sederhana. Kiddo: Jurnal Pendidikan Islam Anak Usia Dini, 1(2), 66-79.

Suryana, D. (2013). Pendidikan Anak Usia Dini.

Tilaar, H. A. R. (1998). Beberapa agenda reformasi pendidikan nasional dalam perspektif abad 21. IndonesiaTera.

Utami, W. Y. D., Jamaris, M., \& Meilanie, S. M. (2019a). Evaluasi program pengelolaan lembaga PAUD di Kabupaten Serang. Jurnal Obsesi: Jurnal Pendidikan Anak Usia Dini, 4(1), 6776.

Utami, W. Y. D., Jamaris, M., \& Meilanie, S. M. (2019b). Evaluasi Program Pengelolaan Lembaga PAUD di Kabupaten Serang. Jurnal Obsesi: Jurnal Pendidikan Anak Usia Dini, $4(1), 67-76$.

Zulfitrah, Z., \& Eliza, D. (2020). Pengembangan Science Book Anak untuk Pengenalan Literasi dan Karakter Berbasis Budaya Alam Minangkabau. Jurnal Obsesi: Jurnal Pendidikan Anak Usia Dini, 5(2), 1567-1577. 